\title{
Hepatoprotective Effect of Mangosteen Peel Extract on Borax-induced Male Rats
}

\author{
Yunita Satya Pratiwi ${ }^{1}$, Bambang Wirjatmadi ${ }^{2}$, Mangestuti Agil ${ }^{3}$, Merryana Adriyani ${ }^{4}$, Supriyadi $^{5}$ \\ ${ }_{1,2,4}$ Department of Public Health, Airlangga University, Indonesia \\ ${ }^{3}$ Department of Pharmacy, Airlangga University, Indonesia \\ ${ }^{5}$ Department of Health Science, Jember Muhammadiyah University, Indonesia
}

\begin{tabular}{|c|c|}
\hline Article Info & ABSTRACT \\
\hline Article history: & The aim of this study was to determine the hepatoprotective effect of \\
\hline Received Jun 25, 2016 & Hepatoprotective effect is represented by the variables of liver weight, SGOT \\
\hline Revised Aug 18, 2016 & (Serum Glutamic oxaloacetic transaminase) and SGPT (Serum Glutamic \\
\hline Accepted Aug 26, 2016 & $\begin{array}{l}\text { Pyruvate Transaminase). The true experimental study used randomized } \\
\text { separated pretest-posttest control group design. MPE was made with } 50 \%\end{array}$ \\
\hline Keyword: & $\begin{array}{l}\text { ethanol and } 0.5 \% \text { carboxymethyl cellulose-sodium (CMC-Na) stabilizer } \\
\text { solutions. Studied groups included three control groups (positive, negative }\end{array}$ \\
\hline Borax & pretest and posttest) and three experimental groups (MPE dose of $200 \mathrm{mg} / \mathrm{kg}$, \\
\hline Hepatoprotective & $\begin{array}{l}400 \mathrm{mg} / \mathrm{kg} \text { and } 600 \mathrm{mg} / \mathrm{kg} \text { rats body weight }(\mathrm{BW}) \text { ). Samples consisted } 36 \\
\text { male rats. The length of intervention was } 16 \text { days by providing borax, and }\end{array}$ \\
\hline Liver Weight & then MPE was started on day 3 (in 3 experimental groups). Results showed \\
\hline Mangosteen peel extract & that up to 16 th day the SGOT tended to decrease $(\alpha<0.05)$, while the SGPT \\
\hline SGOT & levels was stable, and so was the liver weight. Thus, up to day 16 the MPE \\
\hline SGPT & $\begin{array}{l}\text { was generally able to provide hepatoprotective effects mainly based on the } \\
\text { variable SGOT in doses of } 200 \text { and } 400 \mathrm{mg} / \mathrm{kg} \text {. It has been proved that liver } \\
\text { function of the rats was still relatively normal. This is in relations to the } \\
\text { antioxidant potential of the MPE polyphenols. }\end{array}$ \\
\hline
\end{tabular}

Copyright () 2016 Institute of Advanced Engineering and Science. All rights reserved.

\section{Corresponding Author:}

Yunita Satya Pratiwi,

Department of Health Science,

Jember Muhammadiyah University,

Karimata road No. 49, Jember, East Java, Indonesia.

Email : yunitasatyapratiwi@gmail.com

\section{INTRODUCTION}

Results of Food Safety Survey by NADF RI 2009 to 1504 Household Food Industries (Industri Rumah Tangga Pangan, IRTP) in 18 provinces showed that, compared to others, the majority of non-food grade additives abused was borax (8.80\%) [1]. The main danger to health from borax use is that the residues it left behind can cause systemic effects on the body. In addition to its visible influence from outside, such as hardening of the skin and outer skin tissue death, more harmful effects are related to damages of liver, stomach, small intestine, colon, infertility of the testes and ovaries, as well as stimulating the growth of cancer cells. Borax that attack cells, especially in mitochondria, accumulates in the cytoplasm that interfere with cell metabolism. In high doses in the body, borax will cause dizziness, vomiting, diarrhea, abdominal cramps, low blood pressure, anemia, fever and damage to other organs, including brain, and even death [2], [3].

These negative impacts occur because borax is a source of free radicals [4] particularly superoxide radical $\left(\mathrm{O}^{*}{ }^{*}\right)$, that is very strong and can damage cells [5]. Borax has chemical properties that is able to bind the hydroxyl group $\left(\mathrm{OH}^{-}\right)$on glucose and glycogen, as well as binding $\mathrm{NAD}^{+}$coenzyme containing ribose component which are active in energy metabolism pathways the glycolysis [6], [7]. 
According to the research results, liver is a site where borax is found in high concentrations, in addition to brain and kidneys [8]. The liver is the largest organ where many processes of energy metabolism, lipid, carbohydrate and protein, take place. In this case, the liver is able to detox xenobiotic or toxins that enter the body, and vulnerable to the effects of toxic substances [9], [10].

The finding of borax in high concentrations in the liver will cause a negative impact on liver cells. Studies showed that degeneration and necrosis had already occurred in experimental rats liver histopathology on day 14 after borax administration [11]. Liver damage is always associated with cell necrosis, increased lipid peroxidation and decreased levels of tissue GSH (Glutathione). Other biochemical indicators in blood serum level are the level of SGOT (Serum Glutamic oxaloacetic transaminase), SGPT (Serum Glutamic Pyruvate Transaminase), ALP (Alkaline Phospatase) and bilirubin [12].

In addition, organ weights and weight loss are indication of organ injury. Changes in organ weights have long been accepted as a sensitive indicator of chemical changes in organs [13], [14].

In relations to the occurrence of hepatotoxicity due to borax induction in mice, it is necessary to protect the liver (hepatoprotective) by using plants containing phytochemicals that can serve as antioxidant as well as free radicals scavenger to neutralize free radicals and able to protect coenzyme NAD ${ }^{+}$level.

This study used herbs, mangosteen peel (Garcinia mangostana Linn), which contain high polyphenols antioxidants kind, such as xanthones [15], phenolic acid, flavonoids [16], catechins (including flavonoid), hexadecanoic acid, and oleic acid. The compound xanthones is an antioxidant found in mangosteen fruit peel. Such compounds have antioxidant activity because of its phenol group [17]. Additionally, mangosteen peel contains flavonoids that is supposedly able to protect NAD ${ }^{+}$level in the cell [18],[19].

The aim of this study was to determine hepatoprotective effect of mangosteen peel extract (Garcinia mangostana L) in borax-induced male rats (Rattus norvegicus) by measuring the weight of the liver, SGOT and SGPT.

\section{RESEARCH METHOD}

\subsection{Research type and design}

This was a true experimental study, using randomized separated pretest-posttest control group design. There were three types of groups: negative control group $\{(2$ sub-groups: pretest (K1) and posttest (K2)\}, positive control group (K3) and mangosteen treatment group (3 subgroups: group P4, P5 and P6), totally there were 6 groups.

\subsection{Samples and sample size}

Samples used were white experimental rats (Rattus norvegicus) of Wistar strain, with inclusion criteria of male, aged 3-4 months, healthy and active. While the exclusion (drop out) criteria were unwilling to eat, ill, stress, inactive, and died before and after obtaining treatment. There were six studied groups (K1, $\mathrm{K} 2$, K3, P4, P5 and P6), and each group takes 6 mice, the total sample size was 36 rats.

\subsection{Herbs and experimental animals}

Materials used were dark purple mangosteen fruit from mangosteen plantation in black from Trengglek district. Harvest Age was 104-110 days after flowering.

The experimental animals were male Wistar strain Rattus norvegicus, aged 3-4 months, body weight ranged between 150-250 g, purchased from a rats breeder in Bangil, Pasuruan, under the supervision of the Faculty of Veterinary Medicine, University of Airlangga, Surabaya. Rat feed was pellet produced by PT. Charoen Pokphand Surabaya. Rats' drinking water was gallon water of the brand Aqua. Before treatment, the experimental animals were acclimatized for 16 days during which they were given with standard feed, ad libitum drink, ambient temperature, air humidity between 40-60\%.

\subsection{Chemical substances and instruments}

Chemicals for producing mangosteen peel extract includes a sterile distilled water, $50 \%$ ethanol, CMC-Na (Carboxymethyl cellulose) for stabilizing a solution of mangosteen peel extract, borax (sodium tetraborate decahydrate), chloroform for rats anesthesia, and $10 \%$ formaldehyde buffer to preserve rat organs. As for the phytochemicals (polyphenols and flavonoids) screening of mangosteen peel filtrate we used chloroform-ethyl acetate-formic acid, $\mathrm{FeCl} 3$, chloroform-methanol, and ammonia vapors. For the analysis of SGOT and SGPT values, the chemical materials were assay buffer, LDH, co-substrate, NADH, dry reagent, $\mathrm{dH} 2 \mathrm{O}$ and enzyme mix.

For maintenance, treatment and blood sampling, instruments needed were cage (containing 3-4 mice), surgical scissors, scalpel blade, tweezers, gloves, pines, digital scales, organ scale, electronic scales 
pocket brand Camry EHA401 models, syringe, stomach sonde, and blood serum. Instruments used to measure the SGPT and SGOT were pipettes, cuvette, syringe, centrifuge, and spectrophotometers.

Tools for making mangosteen peel extract were mill pulverization, glass jars, paper filters, Buchner funnel filter, tubing Erlenmeyer tube, Buchirotary vapor-R-116, Buchi rotary vapor-R-200, Branson ultrasonic 3510, freeze dryer Eyela model of FD-81, Sanyo ultralow Freezer, gram scales, and an analytical balance.

\subsection{Mangosteen peel extract and doses}

The making of mangosteen peel extract (MPE) used maceration and sonication methods, with a polar solvent of 50\% ethanol. As much as $500 \mathrm{mg}$ mangosteen peel powder, whose the outer peel had been removed, was mixed with $2 \mathrm{~L}$ of $50 \%$ ethanol until it became homogeneous, deposited for 24 hours (maceration process), sonicated for 15 minutes and filtered. It was repeated 5 times to form the filtrate. Then it was evaporated with rotavapour $\left(45^{\circ} \mathrm{C}\right)$ to form a viscous extract. Furthermore, it was freeze dried for 24 hours, which eventually the extract was formed in the form of dry powder. The yield was $15 \%$ formed. The dose applied was $200 \mathrm{mg} / \mathrm{kg}, 400 \mathrm{mg} / \mathrm{kg}$ and $600 \mathrm{mg} / \mathrm{kg}$ rat BW.

\subsection{Borax solution and doses}

Borax used has a chemical term sodium tetraborate decahydrate, as a white powder in the solvent of distilled water, mixed until homogeneous. Borax dose applied was approximately $261.1 \mathrm{mg} / \mathrm{kg}$ of rat body weight/day.

\subsection{Preparations for treatment}

Preparation MPE given with sonde to the mice are was MPE suspension in CMC-Na (Carboxy Methyl Cellulose-Sodium) $0.5 \%$.

\subsection{Procedure}

Before the intervention, pretest negative control mice (K1) was not given anything. Posttest negative control (K2) was given only with $0.5 \%$ CMC-Na solution, starting on day 1 to 16 . The positive control (K3) was given only with borax solution to day 16. Treatment in the three groups of rats with borax (from day 1 to day 16) was followed with the provision of MPE starting on day 3 to 16 using a stomach sonde in 3 doses of $200 \mathrm{mg} / \mathrm{kg}$ bw (P4), $400 \mathrm{mg} / \mathrm{kg}$ bw (P5) and $600 \mathrm{mg} / \mathrm{kg} \mathrm{bw} \mathrm{(P6),} \mathrm{1-2} \mathrm{ml} \mathrm{per} \mathrm{rat.} \mathrm{Pretest} \mathrm{of} \mathrm{day} 0$ and posttest of day 17 was done by scaling liver weight, and measuring SGPT and SGOT levels in their blood serum.

\subsection{SGOT and SGPT test methods}

SGOT examination procedure, directly by measuring AST (aspartate transaminase) activity based on the amount of oxaloacetate produced by AST. In this test, oxaloacetate and NADH were converted into malate and NAD by malate dehydrogenase enzyme. Decreased levels of NADH at $340 \mathrm{~nm}$ absorbance was proportional and in accordance with the AST activity. Working stages were three: stage of using 96 wells plate, stage of using cuvettes, and stage of measurement.

SGPT examination procedure, indirectly by measuring the activity of ALT (Alanine transaminase) based on the amount of pyruvate produced by ALT. In this test, pyruvate and NADH were converted into lactate and NAD by the enzyme lactate dehydrogenase (LDH). Decreased levels of NADH at $340 \mathrm{~nm}$ absorbance was proportional to the ALT activity. Working stages were three: stage of using 96 plate wells, stage of using cuvettes, and stages of measurement.

\subsection{Statistical analysis}

Data analysis was performed using IBM SPSS statistics 21 for windows as follows: a) analysis with descriptive statistics, b) test for normality of data distribution with the Kolmogorov-Smirnov test, c) homogeneity test by Levene's test, d) comparative test, between groups before and after being treated with one way ANOVA (Analysis of Variance). on $\alpha=0.05$, and e) a further test with post-hoc multiple-comparison test with Tukey test [20], f) if the data were not homogeneous or not normally distributed, then tested with non-parametric comparative Kruskal Wallis test, g) test further use is non-parametric Mann Whitney test.

\section{RESULTS AND ANALYSIS}

\subsection{Liver weight}

Results of measurements of the weight average of the liver in each study group are presented in

Table 1. We can see below this. 
Table 1. Weight Average of the LIVER in each Studied Groups

\begin{tabular}{ccc}
\hline No. & Studied groups & $\begin{array}{c}\text { Weight Average of the liver } \\
(\mathrm{x} \pm \text { standard deviation }) \mathrm{gr}\end{array}$ \\
\hline 1 & K1 & $7.05 \pm 0.25$ \\
2 & K2 & $6.59 \pm 0.74$ \\
3 & K3 & $7.35 \pm 0.60$ \\
4 & P4 & $6.60 \pm 0.85$ \\
5 & P5 & $7.21 \pm 0.69$ \\
6 & P6 & $7.26 \pm 1.32$ \\
\hline
\end{tabular}

The significance level $(\alpha)$ of Kruskal Wallis comparative test is $0.435(\alpha>0.05)$.

Notes:

$\mathrm{K} 1=$ pretest negative control group, not receiving anything on day 0

$\mathrm{K} 2=$ posttest negative control, receiving only a solution of $0.5 \% \mathrm{CMC}-\mathrm{Na}$ from day 1 to day 16

$\mathrm{K} 3=$ positive control group, receiving only borax dose of $261.1 \mathrm{mg} / \mathrm{kg}$ bw/day from day 1 to day 16

$\mathrm{P} 4=$ treatment group, receiving borax of $261,1 \mathrm{mg} / \mathrm{kg}$ bw/day from day 1 to day 16 , and receiving mangosteen peel extract of $200 \mathrm{mg} / \mathrm{kg} /$ day starting on day 3 to day 16

P5 = treatment group, receiving borax of $261,1 \mathrm{mg} / \mathrm{kg}$ bw/day from day 1 to day 16 , and receiving mangosteen peel extract dose of $400 \mathrm{mg} / \mathrm{kg}$ bw/day starting on day 3 to day 16 .

P6 = treatment group receiving borax of $261,1 \mathrm{mg} / \mathrm{kg}$ bw/day from day 1 to day 16 , and receiving mangosteen peel extract dose of $600 \mathrm{mg} / \mathrm{kg} /$ day starting on day 3 to day 16 .

Complete results of liver weight measurements are presented in Figure 1 below this.

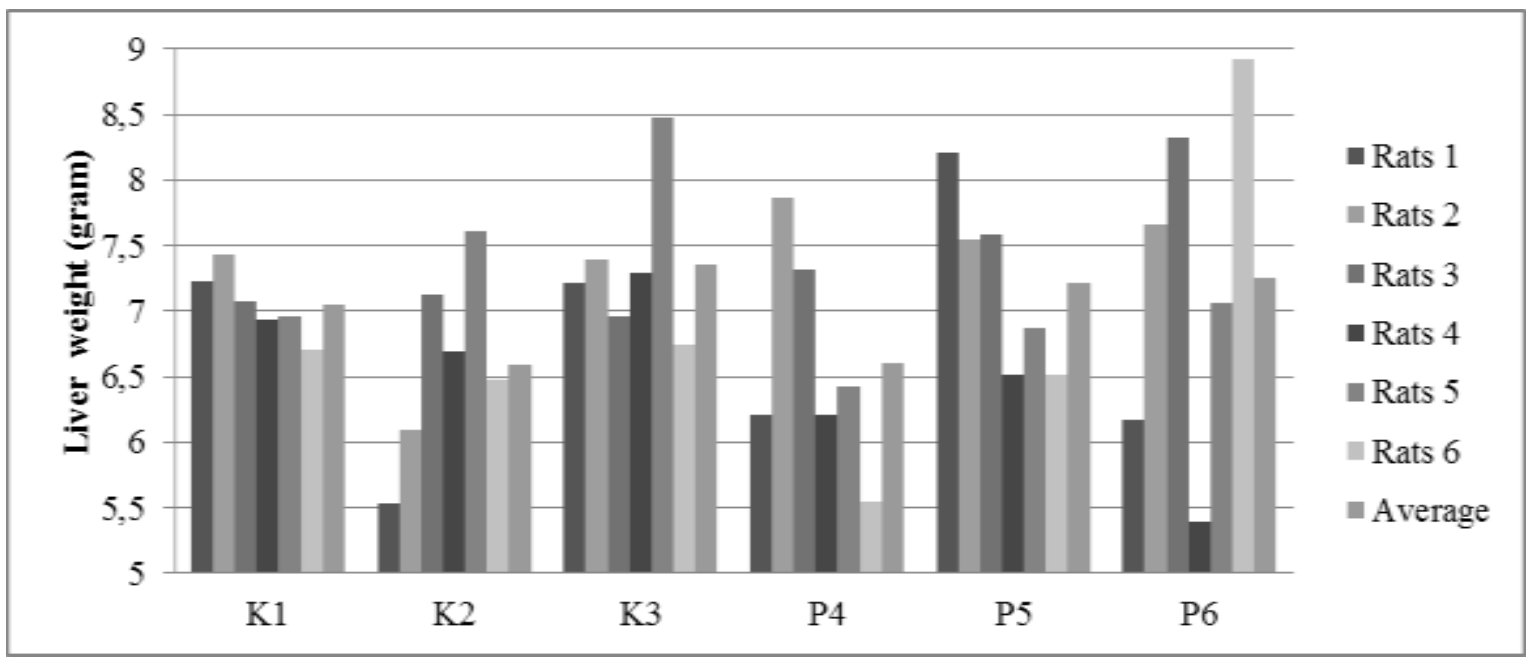

Figure 1. Results of liver weight measurements and the average in rats

Descriptively the average weight of the liver was the highest in group K3 as shown in Figure 1. Results of statistical tests revealed normally distributed data $(\alpha>0.05)$, but not homogeneous $(\alpha=0.035)$. Results of non parametric Kruskal Wallis test revealed $\alpha=0.435(\alpha>0.05)$, indicating no significant difference between one group and the others. Thus, the organ weight did not increase.

Boric acid causes a decrease in the concentration of metabolites such as glucose, glycogen and lactate, due to the formation of complexes between boron and hydroxyl compounds. In addition, boric acid causes damage to some parts of mitochondria. Lack of ATP metabolites and breakdown of mitochondrial metabolism is harmful to the survival and function of cells, especially tissue that dependends highly on energy, such as skeletal muscle [21]. Borax has chemical properties that is able to bind hydroxyl group (OH-) on glucose and glycogen, as well as binding coenzyme $\mathrm{NAD}^{+}$containing ribose component which are active in energy metabolism pathways, the glycolysis [6],[7].

Impaired energy metabolism that causes a decrease in ATP synthesis, which occurs as in ischemic disorder, will cause $\mathrm{Na}^{+}$and $\mathrm{Ca}^{2+}$ pump experience a shortage of energy and causes more $\mathrm{Na}^{+}, \mathrm{Ca}^{2+}$ and $\mathrm{H}_{2} \mathrm{O}$ flow into the cell (influx), while more $\mathrm{K}^{+}$to flow out of the cell (efflux). Consequently, swelling occurs from endoplasmic reticulum to the cell. Such cellular swelling is the first manifestation of virtually all forms of cell injury. When it affects the cells in the organ, it will cause paleness, increased turgor, and increased organ weights [22]. 
The increase in organ weight is one indicator of cell injury due to the use of chemicals. Analysis of organ weights in toxicology studies is an important final point to identify potential harmful effects of chemicals [23]. Descriptively, organ weight of the positive control group, after 16 days of intervention, had the highest increase, although it was not different significantly from the other groups. However, the results showed that rats' liver that had been induced with borax for 16 days did not show significant increase in weight after being given with mangosteen peel extract. It was suspected there was the role of mangosteen peel extract polyphenols in protecting the organ from cellular swelling that can lead to an increase in weight of the liver. Moreover, mangosteen peel contains flavonoids that is allegedly able to protect $\mathrm{NAD}^{+}$level in the cell [18], [19], so as to prevent ATP production decline which also have an impact on cellular swelling. The lowest (the best) average organ weight was that in group receiving MPE of $200 \mathrm{mg} / \mathrm{kg}$.

\subsection{SGOT}

Results of measurements of the SGOT average of the liver in each study group are presented in Table 2. And results of post hoc test comparing difference between groups are presented in Table 3 . We can see all below this.

Table 2. The SGOT Average in Rats Serum in each Studied Groups

\begin{tabular}{ccc}
\hline No. & Studies groups & $\begin{array}{c}\text { SGOT Average } \\
(\mathrm{x} \pm \text { standard deviation }) \mathrm{U} / \mathrm{L}\end{array}$ \\
\hline 1 & $\mathrm{~K} 1$ & $91.00 \pm 9.65$ \\
2 & $\mathrm{~K} 2$ & $105.33 \pm 22.68$ \\
3 & $\mathrm{~K} 3$ & $125.00 \pm 14.85$ \\
4 & $\mathrm{P} 4$ & $95.67 \pm 9.58$ \\
5 & $\mathrm{P} 5$ & $87.00 \pm 12.63$ \\
6 & $\mathrm{P} 6$ & $117.33 \pm 13.63$ \\
\hline
\end{tabular}

The significance level $(\alpha)$ of comparative Anova test between all groups is $0.00(\alpha<0.05)$.

Table 3. Results of post hoc "Tukey" test comparing difference between groups

\begin{tabular}{|c|c|c|c|}
\hline No & Between Groups & Significance $(\alpha$ count $)$ & Correlation \\
\hline 1 & $\mathrm{~K} 1-\mathrm{K} 2$ & 0.536 & Not significantly different \\
\hline 2 & $\mathrm{~K} 1-\mathrm{K} 3$ & 0.040 & Significantly different \\
\hline 3 & $\mathrm{~K} 1-\mathrm{P} 4$ & 0.993 & Not significantly different \\
\hline 4 & $\mathrm{~K} 1-\mathrm{P} 5$ & 0.997 & Not significantly different \\
\hline 5 & $\mathrm{~K} 1-\mathrm{P} 6$ & 0.040 & Significantly different \\
\hline 6 & $\mathrm{~K} 2-\mathrm{K} 3$ & 0.208 & Not significantly different \\
\hline 7 & $\mathrm{~K} 2-\mathrm{P} 4$ & 0.855 & Not significantly different \\
\hline 8 & $\mathrm{~K} 2-\mathrm{P} 5$ & 0.273 & Not significantly different \\
\hline 9 & K2 - P6 & 0.708 & Not significantly different \\
\hline 10 & $\mathrm{~K} 3-\mathrm{P} 4$ & 0.017 & Significantly different \\
\hline 11 & $\mathrm{~K} 3-\mathrm{P} 5$ & 0.001 & Significantly different \\
\hline 12 & K3 - P6 & 0.940 & Not significantly different \\
\hline 13 & P4 - P5 & 0.903 & Not significantly different \\
\hline 14 & $\mathrm{P} 4-\mathrm{P} 6$ & 0.133 & Not significantly different \\
\hline 15 & $\mathrm{P} 5-\mathrm{P} 6$ & 0.013 & Significantly different \\
\hline $\begin{array}{l}\text { Note } \\
\text { a) } \alpha \\
\text { b) } \alpha\end{array}$ & cant at & & \\
\hline
\end{tabular}

The complete results of SGOT measurements are presented in Figure 2. Based on the results of the study, blood serum levels of AST in all study groups were significantly different $(\alpha=0.00$ or $\alpha<0.05)$. Thus, there was a significant hepatoprotective effect of MPE on the decline in blood serum levels of AST mice that have been induced with borax for 16 days. The highest average level $(125.00 \pm 14.85 \mathrm{U} / \mathrm{L})$ was still in positive control group (receiving only borax for 16 days). AST level was the lowest (the best) in the provision of MPE of $400 \mathrm{mg} / \mathrm{kb}$ bw $(87.00 \pm 12.63) \mathrm{U} / \mathrm{L}$. Functionally, rat's liver function was still relatively normal, because the normal SGOT value in male rats is 60-300 U/L, and female 80-250 U/L [24].

The enzyme aminotransferase (formerly transaminase) is most often used as a specific indicator of hepato-cellular necrosis. The enzyme aspartate aminotransferase (AST, formerly serum glutamic oksaloacetate transaminase or SGOT) and alanine aminotransferase (ALT, formerly serum glutamic pyruvic transaminase or SGPT) catalyzes the transfer of amino group of aspartic acid and alanine respectively to the keto group of ketoglutaric acid. ALT is mainly localized in the liver but AST is present in various tissues such as the heart, skeletal muscles, kidney, brain and liver [25],[26]. 


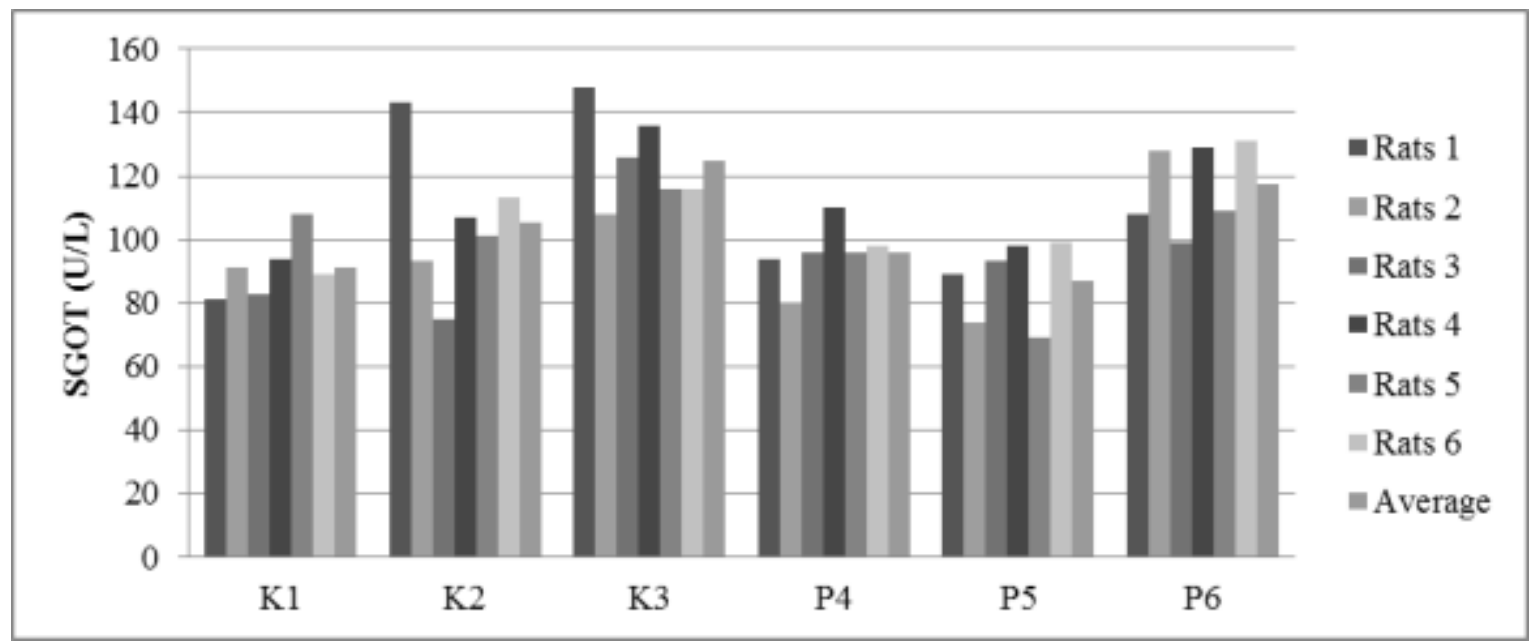

Figure 2. Results of SGOT measurement and the average in rats serum

The results of a study by Octavia (2012) [11], that examined the effect of borax on histopathological profile of the liver in white rats (Rattus norvegicus), using experiment up to day 14 of intervention, showed that borax does not cause congestion, but caused degenerative changes and necrosis in liver cells. And Astiningrum (2011) [27] studied about the effect of borax on liver damage swiss Webster strain of male mice, in which borax was administered in doses of $150,300,450$, and $600 \mathrm{mg} / \mathrm{kg} /$ day for 27 days, evidently in dose of $600 \mathrm{mg} / \mathrm{kg} / \mathrm{day}$ was found to increase SGOT (AST) and SGOT (ALT) levels in mice liver.

AST is present in both mitochondria and cytosol of hepatocytes. ALT is localized to the cytosol [26],[28]. In cytosolic and mitochondria, AST was a true isoenzyme and imunologically distinct [29]. Approximately $80 \%$ of AST activity in human liver is contributed by mitochondrial isoenzyme, whereas most AST activities circulating in normal individuals are derived from cytosolic isoenzymes [25],[30].

ALT cytosol is associated with pyruvate use in glycolysis. ALT mitochondrial is involved in the conversion of alanine to pyruvate in gluconeogenesis, and AST plays an important role in transport across the mitochondrial membrane [31],[32]. Hepatocellular damage due to any disorder allows plasma membrane leakage, so that intracellular enzymes such as ALT or AST flow into the bloodstream. Due to some hepatotoxicants, the increase of liver aminotransferase synthesis also becomes a source of elevated levels of serum enzyme in hepatocellular injury [33]. Increased levels of serum AST occurs in mitochondria after an extensive tissue necrosis. Therefore, mitochondrial AST determination is recommended in miocardial infarction cases and is also elevated in chronic liver disease [34].

Necrosis of the liver tissue occurs due to oxidative stress. Oxidative stress occurs due to excessive generation of free radicals and/or lack of antioxidants (eg, a substance called glutathione, vitamin A and E) to bind the radicals. Oxidative stress occurs in conjunction with the ATP depletion and reduced glutathione levels in the cells [35].

The tendency of AST decrease in blood serum in mice is thought to result from polyphenols contribution of mangosteen peel extract as antioxidants or scavenger of free radicals that prevent oxidative stress in mice liver, which will result in liver necrosis.

Polyphenol is a group of secondary metabolites involved in the cleanup of $\mathrm{H} 2 \mathrm{O} 2$ in plant cells. In this case the polyphenolic compound has a high antioxidant potential, providing protection against cancer by inhibiting oxidative damage, which is known as a potential cause of mutations. Free radicals cause oxidative damage to lipids, proteins, and nucleic acids [36]. Polyphenol antioxidant properties are the main feature of the capacity of scavenging free radicals [37]-[39].

\subsection{SGPT} Table 4.

Results of measurements of the SGPT average of the liver in each study group are presented in 
Table 4. The SGPT Average in Rats Serum in Each Groups

\begin{tabular}{ccc}
\hline No. & Treatment Groups & $\begin{array}{c}\text { SGPT Average } \\
(\mathrm{x} \pm \text { standard deviation) } \mathrm{U} / \mathrm{L}\end{array}$ \\
\hline 1 & $\mathrm{~K} 1$ & $56.67 \pm 5.20$ \\
2 & $\mathrm{~K} 2$ & $47.83 \pm 8.66$ \\
3 & $\mathrm{~K} 3$ & $58.50 \pm 11.47$ \\
4 & $\mathrm{P} 4$ & $49.33 \pm 6.68$ \\
5 & $\mathrm{P} 5$ & $50.50 \pm 5.43$ \\
6 & P6 & $56.83 \pm 6.05$ \\
\hline
\end{tabular}

The significance level $(\alpha)$ of Kruskal Wallis comparative test is $0.189(\alpha>0.05)$.

The complete results of SGPT measurement are presented in Figure 3.

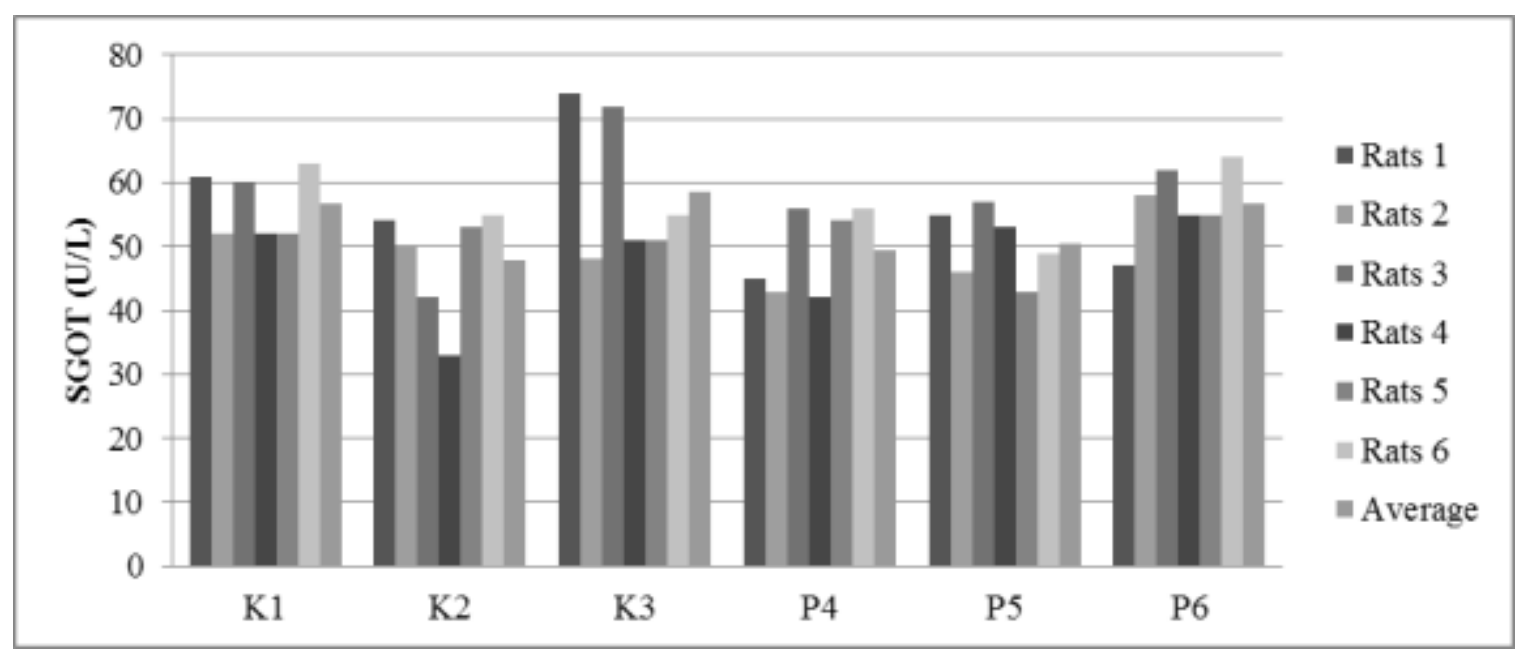

Figure 3. Results of SGPT measurement and the average in rats serum

Based on the research results, ALT level in blood serum of all groups did not differ significantly ( $\alpha$ $>0.05)$. This indicates that rats liver that had been induced with borax for 16 days did not have elevated ALT level significantly after being given with mangosteen peel extract. However, the highest mean $(58.50 \pm 11.47$ $\mathrm{U} / \mathrm{L}$ ) remained in positive control group (receiving only borax for 16 days). The lowest (the best) ALT level was in the provision of mangosteen peel extract of $200 \mathrm{mg} / \mathrm{kb} \mathrm{BW}$. Functionally, liver function of the rats was still relatively normal since the threshold value of normal SGPT in male rats is 25-55 U/L, while in females rats 25-50 U/L [24].

SGPT (ALT or alanine aminotransferase) is an enzyme that catalyzes the transfer of amino groups to form oxaloacetate liver metabolite [40]. This enzyme consists of 496 amino acids, encoded by genes located along the arm of chromosome 8 [41],[42]. Thus, in the case of hepatocellular injury or death, the release of ALT from damaged liver cells is increasing by measuring ALT activity in blood serum. ALT, cytosolic enzyme, is found in highest concentrations in the liver and more specifically to the liver [43]. In addition to the liver, it is also found in kidney, and, in smaller amounts, in skeletal muscle cells [44].

The tendency of stability and slightly decreased ALT level in rats blood serum is suspected to result from the role of MPE polyphenols as antioxidants or free radicals scavenger that prevent oxidative stress in rats liver, which will may result liver necrosis.

Aside from liver disease and damage, ALT serum activity can be influenced by a number of factors unrelated to liver necrosis [44]. Therefore, the variability of ALT levels is allegedly influenced by many factors that could not be predicted in this study.

\section{CONCLUSION AND SUGGESTION}

Results revealed that up to day 16 SGOT was decreasing $(\alpha<0.05)$, while SGPT levels was stable $(\alpha>0.05)$, so was the weight of the liver $(\alpha>0.05)$. The highest average weight of the organ, SGOT and SGPT was in positive control group. In treatment group, the lowest was in group of $200 \mathrm{mg} / \mathrm{kg}$ (for organ 
weights and SGPT) and a group of $400 \mathrm{mg} / \mathrm{kg}$ (in SGOT). Thus, until day 16 MPE was generally able to provide hepatoprotective effects, mainly based on SGOT variable in doses 200 and $400 \mathrm{mg} / \mathrm{kg}$. It has been proved that liver function of the experimental rats was still relatively normal. This happens because there is the role of polyphenols MPE in protecting from cellular swelling that could lead to an increase in liver weight, and there is the role of polyphenols as a protective of $\mathrm{NAD}^{+}$and antioxidant levels, which may protect from rising the levels of SGOT and SGPT due to necrosis from oxidative stress after borax induction.

The use of mangosteen peel extract should be improved as antioxidant supplements. In addition, further studies should be carried out on the protective effects of mangosteen peel extract on organs other than the liver and using other non-food grade additives.

\section{ACKNOWLEDGEMENTS}

I would like to express my deep gratitude to Prof. R. Bambang Wirjatmadi, dr, M.S., M.CN., Ph.D, Sp.GK, Prof. Mangestuti Agil, M.S., Apt., and Dr. Merryana Adriani, S.KM., M.Kes, my research supervisors, for their patient guidance, enthusiastic encouragement and useful critiques of this research work. I would also like to thank to Prof. I Ketut Sudiana, Drs., M.Si. for his advice and assistance in keeping my progress on schedule. My grateful thanks are also extended to Mrs. Evi Arfianti, S. KM., M. Kes., Mr. Sujarwo, Mr. Heri and Mrs Endah for their help in doing at the laboratory pharmacy and biochemical. Finally, I wish to thank my husband, my parents, daughter, sister, brother for their support and encouragement throughout my study.

\section{REFERENCES}

[1] National Agency of Drug and Food of the Republic of Indonesia, "Performance Reports of Food and Drug Administration of the Republic of Indonesia the first semester of 2012," Jakarta, NADF RI, 2012.

[2] M. A. Dourson, B. Maier, F. Meek, R. Bareille, Baquey, "Boron Tolerable Intake Re-evaluation of Toxicokinetics for Data Derived Uncertainty Factors," Biol. Trace Elem. Res, vol/issue: 66(1-3), pp. 453-463, 2003.

[3] C. Lewis, "The "Poision Squad" and the Advent of Food and Drugs Regulation," USA, FDA Consumer Magazine, 2002.

[4] A. Puspadewi, "Giving of Oral Alpha Lipoic Acid (ALA) can lower levels of malondialdehyde (MDA) of Blood Wistar rats (Rattus norvegicus) Induced Oral Borax," Postgraduate Thesis, Denpasar, Udayana University, 2012.

[5] S. Setiati, "Free radicals, antioxidants and aging process," Medika magazine, vol/issue: 6(19), pp. 366-368, 2003.

[6] W. J. Deal, "Metabolic control and structure of glycolytic enzymes IV. Nicotinamide-adenine dinucleotide dependent in vitro reversal of dissociation and possible in vivo control of yeast glyceraldehyde 3-phosphate dehydrogenase synthesis," Biochemistry, vol. 8, pp. 2795-2805, 1969.

[7] F. A. Bettelheim, W. H. Brown, M. K. Campbell, S. O. Farrell, "Introduction to General, Organic, and Biochemistry, Eighth Edition," Kentucky, Thomson Higher Education, 2007.

[8] H. Turkez, F. Geyikoglu, A. Tatar, M. Keles, I. Kaplan, "The effects of Some Boron Compounds against Heavy Metal Toxicity in Human Blood," Exp Toxicol Pathol, vol/issue: 64(1-2), pp. 93-101, 2012

[9] S. A. Smith, "The premaire all national liver/ kidney detox," The live tree, Alabama USA, pp. 142, 2003.

[10] M. Plotken, "Detoxification and drainage," 2007. Dipetik 9 Mei 2016, dari http://www.heelusa. com/file/mice/plotken-detox.october.no29/pdf.

[11] P. Octavia, "Effect of Borax against Liver Histopathology Overview of Rats (Rattus norvegicus)," Surabaya, Faculty of Veterinary Medicine, University of Airlangga, 2012

[12] R. Shukla, S. J. Surana, A. U. Tatiya, S. K. Das, "Investigation of hepatoprotective effects of piperine and silymarin on D-galactosamine induced hepatotoxicity in rats," Research Journal of Pharmaceutical, Biological and Chemical Sciences, vol/issue: 2(3), pp. 975-982, 2011.

[13] J. M. Peters, E. M. Boyd, "Organ weights and water levels of the rat following reduced food intake," J Nutr, vol/issue: 90(4), pp. 354-60, 1966.

[14] C. J. Pfeiffer, "A mathematical evaluation of the thymic weight parameter," Toxicol Appl Pharmacol, vol/issue: 13(2), pp. 220-227, 1968.

[15] H. A. Jung, B. N. Su, W. J. Keller, A. D. Kinghorn, "Antioxiidant Xanthones From The Pericarp Of Garciana Mangostana (Mangoteen)," Journal of Agricultural and Food Chemistry, vol. 54, pp. 2077 - 2082, 2006.

[16] A. Zarena, K. U. Sankar, "Phenolic Acid, Flavonoid Profile and Antioxidant Activity in Mangosteen (Garcinia mangostana L.) Pericarp," Journal Food Biochemistry, vol/issue: 36(5), pp. 627-633, 2012.

[17] Y. I. Miryanti, S. Lanny, B. Kurniawan, I. Stephen, "Antioxidants Extraction from Mangosteen Peel (Garcinia mangostana Linn.)," Bandung, Research Report, Institute for Research and Community Services, Parahyangan Catholic University, 2011.

[18] D. M. Boesten, S. N. Ungern-Sternberg, G. J. Hartog, A. Bast, "Protective Pleiotropic Effect of Flavonoids on NAD+ Levels in Endothelial Cells Exposed to High Glucose," Oxidative Medicine and Cellular Longevity, pp. 1 7, 2014. 
[19] C. Escande, V. Nin, N. L. Price, V. Capellini, A. P. Gomes, M. T. Barbosa, et al., "Flavonoid Apigenin Is an Inhibitor of The NAD+ase CD38: Implications for Cellular NAD+ Metabolism, Protein Acetylation, and Treatment of Metabolic Syndrome," Diabetes, vol. 62, pp. 1084 - 1093, 2013.

[20] D. Flynn, "Student Guide to SPSS," New York, Barnard College, Department of Biological Sciences, 2008.

[21] A. H. Schapira, "Inborn and induced defects of mitochondria," Ar. Neurol, vol. 55, pp. 1293-1296, 1998. DOI: 10.1001/archneur.55.10.1293.

[22] S. L. Robbins, "Cellular adaptation, cell injury, and cell death," in A. A. In: Kumar V., "Robbins and Cotran Pathologic Basis of Disease 7th," pp. 16-18, 324, China, Elsevier. Inc, 2005.

[23] S. A. Bailey, R. H. Zidell, R. W. Perry, "Relationships Between Organ Weight and Body / Brain Weight in the Rat: What Is the Best Analytical Endpoint?," Toxicologic Pathology, vol. 32, pp. 448 - 466, 2004.

[24] R. L. Hall, "Clinical Pathology of Laboratory Animals," in Gad, S.C., (Eds), "Animal Models in Toxocology," Second Edition, New York, Taylor and Frank Group, 2007.

[25] S. F. Friedman, P. Martin, J. S. Munoz, "Laboratory evaluation ofthe patient with liver disease," in "Hepatology, a textbook of liver disease," pp. 1, 661-709, Philedelphia, Saunders publication, 2003.

[26] H. R. Rosen, E. B. Keefe, "Evaluation of abnormal liver enzymes, use of liver tests and the serology of viral hepatitis," in "Liver disease, diagnosis and management 1st ed," pp. 24-35, New York, Churchill livingstone publishers, 2000.

[27] M. A. Astiningrum, "Effect of borax to liver damage of swiss webster strain of male mice, experimental studies by SGPT and SGOT measurement," Semarang, Faculty of Medicine, University of Diponegoro, 2011.

[28] S. Sherlock, "Assessment of liver function Disease of liver and biliary system," in S. Sherlock, 10th edn, pp. 17-32, London, Blackwell science ltd, 1997.

[29] R. M. Green, S. Flamm, "AGA techinal review of evaluation of liver chemistry tests," Gastroenterology, vol. 123, pp. 1367-1384, 2002.

[30] T. R. Boyde, A. L. Latner, "Starch gel electrophoresis of transaminases in human tissues extracts and serum," Biochem J, vol. 82, pp. 52-57, 1961.

[31] Y. Sakagishi, "Alanine aminotransferase (ALT)," Nippon Rin, in McDonald, G. B., Tirumali, N., "Intestinal and liver toxic," sho, vol. 53, pp. 1146-1150, 1995.

[32] R. Rej, “Aminotransferases in disease," Diagn. Enzymol, vol. 9, in LeCluyse, E. L., Audus, K. L., and Hochman, J. H., Formation, pp. 667-687, 1989.

[33] N. J. Pappas, "Source of increased serum aspartate and alanine aminotransferase: Cycloheximide effect on carbon tetra chloride hepatotoxicity," Clin. Chim. Acta, vol. 154, pp. 181-190, 1986.

[34] B. Nalpus, A. Vassault, S. Charpin, et al., "Serum mitochondrial aspartate amonitransferase as a marker of chronic alcoholism diagnostic value and interpretation in a liver unit," Hepatology, vol. 6, pp. 608-613, 1986.

[35] A. F. G. Slater, C. Stefan, I. Nobel, D. V. Dobbelsteen, S. Orrenius, "Signaling mechanisms and oxidative stress in apoptosis," Toxicology Letters, vol. 82, pp. 149 - 153, 1995.

[36] G. H. Shui, L. P. Leong, "Analysis of polyphenolic antioxidants in star fruit using liquid chromatography and mass spectrometry," J Chromatogr A, vol. 1022, pp. 67-75, 2004.

[37] B. Yang, A. Kotani, K. Arai, F. Kusu, "Estimation of the antioxidant activities of flavonoids from their oxidation potentials," Anal Sci, vol. 17, pp. 599-604, 2001.

[38] N. Cotelle, "Role of flavonoids in oxidative stress," Curr Top Med Chem, vol. 1, pp. 569-59, 2001

[39] R. M. Facino, M. Carini, L. Franzoi, O. Pirola, E. Bosisio, "Phytochemical characterization and radical scavenger activity of flavonoids from Helichrysum italicum G. Don (Compositae)," Pharmacol Res, vol. 22, pp. 709-721, 1990.

[40] C. Price, K. Alberti, "Biochemical assessment of liver function," in Wright R et. al., eds., "Liver and biliary diseases - pathophysiology, diagnosis, management," pp. 381-416, London, W.B. Saunders, 1979.

[41] M. Ishiguro, K. Takio, M. Suzuki, R. Oyama, T. Matsuzawa, K. Titani, "Complete amino acid sequence of human liver cytosolic alanine aminotransferase spectral methods," Biochemistry, vol. 30, pp. 10451-10457, 1991.

[42] M. M. Sohocki, L. S. Sullivan, W. R. Harrison, E. J. Sodergren, F. F. Elder, G. Weinstock, et al., "Human glutamate pyruvate transaminase (GPT): localization to 8q24.3, cDNA and genomic sequences, and polymorphic sites," Genomics, vol. 40, pp. 247-252, 1997.

[43] D. S. Pratt, M. M. Kaplan, "Evaluation of abnormal liver enzyme results in asymptomatic patients," N Engl J Med, vol. 342, pp. 1266-71, 2000.

[44] W. R. Kim, S. L. Flamm, A. M. Bisceglie, C. Henry, J. Bodenheimer, "Serum Activity of Alanine Aminotransferase (ALT) as an Indicator of Health and Disease," Hepatology, pp. 1363 - 1370, 2008. 


\section{BIOGRAPHIES OF AUTHORS}
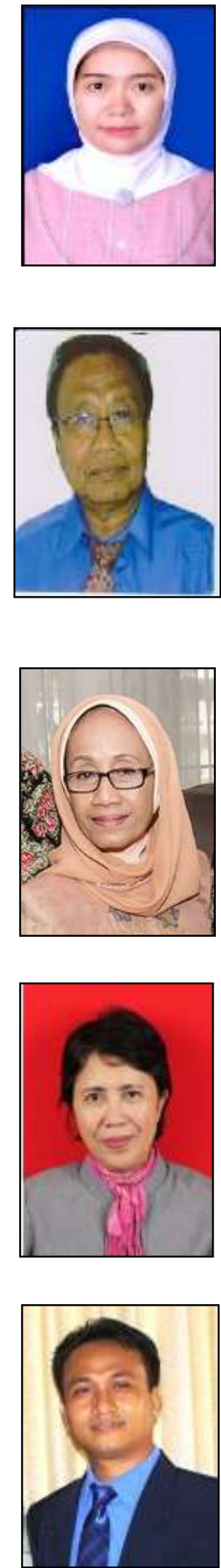

Yunita Satya Pratiwi was born in Pamekasan, East Java province on June 2, 1971. She had completed an undergraduate program of Community Nutrition and Family Resources field in 1975 at Agriculture Faculty, Bogor Agricultural University, in 1996. After a lot of work in the female social organization, in 2006 she was accepted as a lecturer at the Jember Muhammadiyah University. Then she had completed master degree majoring in Public Health Sciences at the Airlangga University in 2009. Now, she become a student at doctoral program in the department of health sciences at the Faculty of Public Health, Airlangga University. She has been doing research and writing scientific articles about public health nutrition both biomedical and social. Now, she is as the chief editor of "The Indonesian Journal of Health Science" at Jember Muhammadiyah University.

R. Bambang Wirjatmadi was born in Wonogiri, Central Java province of Indonesia on March 20,1949 . He had completed an undergraduate program of medical education in 1975 at the Department of General Medicine, Faculty of Medicine, Airlangga University, Surabaya. He had completed master degree majoring in Public Health Sciences at the Airlangga University in 1982 and Community Nutrition at Queensland University, Australia in 1986. In 1993, he had completed a doctoral program at the Department of International Nutrition, Cornell University, USA. He is currently a professor of Clinical Nutrition at the Airlangga University, actively teaches and guides thesis of undergraduate, master and doctoral level. He also did a lot of research especially in the field of clinical nutrition, and a speaker at many national and international seminars. Many publications scientific work that has been done by him in national and international journals. He is a very competent expert in clinical nutrition in Indonesia. He is also a national assessor in the National Accreditation Board of Higher Education in Indonesia.

Mangestuti Agil was born in Jakarta, Indonesia on April 22, 1950. She had completed an undergraduate program of the faculty of pharmacy, Airlangga University in 1976. She has completed master degree majoring in pharmacy at Airlangga University in 1987. In 2000, She had completed the program doctorate at the faculty of Mathematics and natural science, Airlangga University. She is currently a professor of pharmacy, particularly in the field of medicinal plants in the university Airlangga, Surabaya, she actively teaches and guides thesis of undergraduate, master and doctoral level. She also did a lot of research, published many books and a speaker at numerous seminars nationally and internationally, especially the field of medicinal plants. Many publications scientific work that has been done by her in national and international journals. She had ever served as head of the central library at Airlangga University. Until now, she is one of the very competent experts in the field of medicinal plants in Indonesia.

Merryana Adriani was born in Madiun, East Java Province of Indonesia on Mei 17, 1959. She had completed an undergraduate program of faculty of public health, Airlangga University in 1988. She has completed master degree majoring in public health at Airlangga University in 2000 In 2009, she had completed the program doctorate at the faculty of medical science, Airlangga University. He is a lecturer and scientist in the field of public health nutrition are very competent in the national and international levels. She is still actively teaching and guiding thesis of undergraduate, master and doctoral level. She also did a lot of research, published many books and a speaker at numerous seminars nationally and internationally, especially the field of public health nutrition. Many publications scientific work that has been done by her in national and international journals. Now, she is head of academic affairs of Airlangga University, and she is also a national assessor in the National Accreditation Board of Higher Education in Indonesia.

Supriyadi was born in Banyuwangi, East Java Province of Indonesia April 25, 1974. He had completed an undergraduate program of nursing education in 2002 at The Nursing Faculty, Airlangga University, Surabaya. He had completed master degree majoring in Administration and Health Policy, Health Care Management interest at the Airlangga University in 2014. He is a lecturer at Jember Muhammadiyah University. He also did a lot of research especially in nursing field, and a speaker at some national seminars. Some publications scientific work that has been done by him in national journals. He also did a lot of community services in the villages of the Jember District. He had ever served as Dean of the Faculty of Health Sciences, Jember Muhammadiyah University, from 2007 to 2011. 